\title{
Study of Replacement of Compost with Vermicompost and Its Effect on Quality and Quantity Yield and Nutritional Status of Sweet Fennel Plants Grown in Sandy Soil
}

\author{
Abd El-Rheem Kh. M. ${ }^{1}$, Entsar M. Essa ${ }^{2}$ and Heba S. El-Batran ${ }^{3}$ \\ ${ }^{1}$ Soils and Water Use Dept., National Research Centre, Dokki, Cairo, Egypt \\ ${ }^{2}$ Plant Nutrition Dept., National Research Centre, Dokki, Cairo, Egypt \\ ${ }^{3}$ Vegetable Research Dept., National Research Centre, Dokki, Cairo, Egypt \\ Correspondence Author: Abd El-Rheem Kh. M., Soils and Water Use Dept., National Research Centre, Dokki, Cairo, Egypt \\ E-mail: khaled_abdelrheem@yahoo.com
}

Received date: 12 September 2019, Accepted date: 28 November 2019, Online date: 12 December 2019

Copyright: (c) 2019Abd El-Rheem Kh. M. et al., This is an open-access article distributed under the terms of the Creative Commons Attribution License, which permits unrestricted use, distribution, and reproduction in any medium, provided the original author and source are credited.

\begin{abstract}
Two field experiments were carried out at the Agricultural Production and Research Station, National Research Centre (NRC), Nubaria Province, Egypt during successive winter season 2017 and 2018. The experiment was designed to investigate the effect of vermicompost as an alternative to organic compost and its effect on quality and quantity yield and nutritional status of sweet fennel plants (Foeniculum vulgare var. Dulce) grown in sandy soil. Six treatments were added in five replications, where compost and vermicompost were added at a rate of $100 \%$ (5 ton per feddan, which is the recommended doses in the Ministry of Agriculture). Vermicompost was added at rates of $25 \%$ and $50 \%$. The compost and vermicompost were mixed at $75 \%$ and $25 \%$, and $50 \%$ to $50 \%$ respectively. The results indicated that the addition of vermicompost to organic compost given higher results than adding them individually. The highest values of branches number per plant, plant length $(\mathrm{cm})$, fresh and dry weight of shoot and bulb $(\mathrm{g})$ and total green yield (ton $\mathrm{fed}^{-1}$ ) were obtained when using $50 \%$ vermicompost and $50 \%$ compost. The addition of vermicompost (100\%) improved the bulb dimensions (Length, width and thickness) of sweet fennel. As well as the presence of vermicompost improved the nutrients content compared to the compost, even if the vermicompost was added to the compost in different proportions. Through the previous results can be saidsuperiority of vermicompost compared to compost if the two are added to sweet fennel grown in sandy soil. Vermicompost is exemplary organic fertilizer for bestead growth and high yielding of crops.
\end{abstract}

Keywords: Sweet Fennel, Vermicompost, Compost, Yield, Nutrients content, sandy soil

\section{INTRODUCTION}

Sweet fennel is a well-known aromatic medicinal plant which is utilized in imitative medicine [1]. It is planted and diffused in numerous parts of North Africa, Southern Europe and Asia [2]. Sweet fennel fruits are used in the outfit of assorted 
dished like soup, sauces, pastries, confectioneries, pickles and meat dishes. The leaf stalks and the tender shoots are also used in salads, as well as it is used in cooking for liqueurs [3]. Composting generally sorts out as the biological aerobic transformation of an organic by-product into several natural products that can be added to the soil without ferocious effects on yield growth [4]. The composting process recycled organic wastes into products is used to soils as a source of organic matter [5].

Vermi technology is an eco-friendly process for converting the organic wastes into worthy vermigold by utilize an epigeic species of earthworms. The procedure is known as vermicomposting. Vermicompost is the products derived from the accelerated biological degradation of organic wastes by earthworms and microorganisms. The matured casts are known as vermicompost, which can have excellent physical and chemical properties. Earthworms are the most crucial soil-dwelling organisms involved in the process of soil formation and organic matter decomposition [6,7]. Vermicompost has the potential to be an important soil conditioner in agriculture, as its nutrient-rich nature foster plant growth. The main purpose of vermicompost is to recycle organic residues into a nutritive product [8]. Vermicompost is produced as an alternative to fertilizer to improve plant growth while not at the outlay of the environment. Vermicompost increased the bioavailability of nutrients from mineralization, which encourages high germination and dry matter production of plants $[\mathbf{9 , 1 0 ]}$.

The research aimed to study the possibility of substituting compost with vermicompost and their effect on quality and quantity as well as the nutritional status of sweet fennel plants grown in sandy soils.

\section{MATERIALS AND METHODS}

Two field experiments were carried out at the Agricultural Production and Research Station, National Research Centre (NRC), Nubaria Province, Egypt during successive winter season 2017 and 2018. The experiment was designed to investigate the effect of vermicompost as an alternative to organic compost and its effect on quality and quantity yield and nutritional status of sweet fennel plants grown in sandy soil. Seeds of head sweet fennel (cv. Dulce) were sown on September 2017 and 2018 in polystyrene trays. After four weeks from sowing, the transplants were planted in the open field. Sweet fennel seedlings were placed in double rows on October 2017 and 2018. Raised beds with one-meter width were prepared one week before transplanting. Sweet fennel was cultivated two rows for every bed. The final plant spacing was $50 \mathrm{~cm}$ in the row, $60 \mathrm{~cm}$ between the rows and $70 \mathrm{~cm}$ in between the beds. The following treatments were used:

1- Compost at a rate of $100 \%$ ( 5 ton per feddan, which is the recommended doses in the Ministry of Agriculture) $\left(\mathrm{T}_{1}\right)$.

2- Vermicompost at a rate of $25 \%$ (1.25 ton per feddan) $\left(\mathrm{T}_{2}\right)$.

3- Vermicompost at a rate of $50 \%$ (2.50 ton per feddan) $\left(\mathrm{T}_{3}\right)$.

4- Vermicompost at a rate of $100 \%$ (5 ton per feddan) $\left(\mathrm{T}_{4}\right)$.

5- Vermicompost at a rate of $25 \%\left(1.25\right.$ ton per feddan)+ compost at a rate of $75 \%(3.75$ ton per feddan $)\left(\mathrm{T}_{5}\right)$.

6- Vermicompost at a rate of $50 \%(2.50$ ton per feddan $)+$ compost at a rate of $50 \%(2.5$ ton per feddan $)\left(\mathrm{T}_{6}\right)$.

Each treatment was added and five replications.

Some physical and chemical properties of the soil used in Table (1) using the standard procedures outlined by Cottenie[11].

Table 1: Some physical and chemical properties of the soil used

\begin{tabular}{|c|c|c|c|}
\hline Soil property & Value & Soil property & Value \\
\hline \multicolumn{2}{|c|}{ Particle size distribution \% } & $\mathrm{pH}(1: 2.5$ soil suspension $)$ & 7.70 \\
\hline Sand & 92.65 & EC $\left(\mathrm{dS} \mathrm{m}^{-1}\right)$, soil paste extract & 1.60 \\
\hline Silt & 5.07 & \multicolumn{2}{|l|}{ Soluble ions $\left(\mathrm{mmol} \mathrm{L}^{-1}\right)$} \\
\hline Clay & 2.28 & $\mathrm{Ca}^{++}$ & 8.02 \\
\hline Texture & Sandy & $\mathrm{Mg}^{++}$ & 3.23 \\
\hline $\mathrm{CaCO}_{3} \%$ & 2.20 & $\mathrm{Na}^{+}$ & 3.92 \\
\hline Saturation percent $\%$ & 22.50 & $\mathrm{~K}^{+}$ & 0.91 \\
\hline Organic matter\% & 0.11 & $\mathrm{CO}_{3}^{--}$ & nd \\
\hline Available $\mathrm{N}\left(\mathrm{mg} \mathrm{kg}^{-1}\right)$ & 20.2 & $\mathrm{HCO}_{3}^{-}$ & 2.20 \\
\hline Available $\mathrm{P}\left(\mathrm{mg} \mathrm{kg}^{-1}\right)$ & 3.50 & $\begin{array}{l}\mathrm{Cl}^{-} \\
\mathrm{SO}_{4}^{--}\end{array}$ & $\begin{array}{l}3.98 \\
9.90\end{array}$ \\
\hline Available $\mathrm{K}\left(\mathrm{mg} \mathrm{kg}^{-1}\right)$ & 66.4 & $\mathrm{CEC}\left(\mathrm{cmol} \mathrm{kg}^{-1}\right)$ & 7.00 \\
\hline
\end{tabular}

The vermicompost used in this experiment was made of cattle and horse manure and using one species of earthworm (Eisenia fetida). Vermicompost was determined (Table, 2) using the standard procedures outlined by Cottenie[11].

Table 2: Some chemical properties of vermicompost used

\begin{tabular}{|c|c|c|c|c|c|c|c|c|c|}
\hline $\mathbf{p H}$ & $\begin{array}{c}\text { EC (dS } \\
\left.\mathbf{m}^{-\mathbf{1}}\right)\end{array}$ & $\begin{array}{c}\text { Moisture content } \\
(\boldsymbol{\%})\end{array}$ & $\begin{array}{c}\text { Organic matter } \\
\mathbf{( \% )}\end{array}$ & $\begin{array}{c}\text { Organic carbon } \\
(\boldsymbol{\%})\end{array}$ & $\begin{array}{c}\text { Ash } \\
(\boldsymbol{\%})\end{array}$ & $\begin{array}{c}\mathbf{C} / \mathbf{N} \\
\text { ratio }\end{array}$ & $\begin{array}{c}\mathbf{N} \\
(\boldsymbol{\%})\end{array}$ & $\begin{array}{c}\mathbf{P} \\
(\boldsymbol{\%})\end{array}$ & $\begin{array}{c}\mathbf{K} \\
(\boldsymbol{\%})\end{array}$ \\
\hline 6.90 & 2.00 & 15 & 50.3 & 29.2 & 49.7 & $1: 24.3$ & 1.20 & 0.50 & 0.80 \\
\hline
\end{tabular}

The compost used in this experiment was made of cattle manure (50\%) mixing with plant residues (50\%). Compost was determined (Table, 3 ) using the standard procedures outlined by Cottenie[11]. 
Table 3: Some chemical properties of compost used

\begin{tabular}{|c|c|c|c|c|c|c|c|c|c|}
\hline $\mathbf{p H}$ & $\begin{array}{c}\mathbf{E C} \mathbf{( d S} \\
\left.\mathbf{m}^{-1}\right)\end{array}$ & $\begin{array}{c}\text { Moisture content } \\
(\boldsymbol{\%})\end{array}$ & $\begin{array}{c}\text { Organic matter } \\
(\boldsymbol{\%})\end{array}$ & $\begin{array}{c}\text { Organic carbon } \\
(\boldsymbol{\%})\end{array}$ & $\begin{array}{c}\text { Ash } \\
(\boldsymbol{\%})\end{array}$ & $\begin{array}{c}\mathbf{C} / \mathbf{N} \\
\text { ratio }\end{array}$ & $\begin{array}{c}\mathbf{N} \\
(\boldsymbol{\%})\end{array}$ & $\begin{array}{c}\mathbf{P} \\
(\boldsymbol{\%})\end{array}$ & $\begin{array}{c}\mathbf{K} \\
(\boldsymbol{\%})\end{array}$ \\
\hline 8.04 & 3.4 & 23 & 30.8 & 17.9 & 69.2 & $1: 20.8$ & 0.86 & 0.16 & 0.59 \\
\hline
\end{tabular}

DATA RECORDED

\section{1) Vegetative growth characteristics:}

Five plants of each experimental plot were taken at harvest (after 70 days from the transplanting date) to determine growth parameters. The following data were recorded, i.e. plant length $(\mathrm{cm})$, the number of branches per plant, bulb dimensions (thickness, width and length $(\mathrm{cm})$, fresh and dry weight of shoot and bulb $(\mathrm{g})$.

\section{2)Total green yield and quality:}

All the plants of every plot of the experimental plot were harvested at 120 days from transplanting and the data were recorded:-

1- The total yield of sweet fennel plants (ton $\mathrm{fed}^{-1}$ ).

2- Physical bulb quality: Bulbs of such plants were excised by cutting $5 \mathrm{~cm}$ above the bulb using a sharp stainless steel knife. Also, the root was excised and the outer-leaf was removed for obtaining clean bulbs. Afterwards, flatten, cylinder and elongated shape ratios of bulbs were calculated according to Pascale and Barbieri [12] as follow:

* Flatten shape ratio $=\mathrm{W} / \mathrm{T}$

* Cylinder shape ratio $=\mathrm{L} /(\mathrm{WT}) * 0.05$

* Elongated shape ratio $=\mathrm{L} / \mathrm{W}$

Where: W, width (cm); T, thickness (cm); L, length (cm).

\section{3) Nutritional status:}

Five plant samples of each plot were dried at $70{ }^{\circ} \mathrm{C}$ in air forced oven until a constant mass was reached. The sample grounded for chemical analysis and wet digested using $\mathrm{H}_{2} \mathrm{SO}_{4}: \mathrm{H}_{2} \mathrm{O}_{2}$ method [11]. Total nitrogen was determined using the microKjeldahl method. $\mathrm{P}$ was assayed using the molybdenum blue method and determined by spectrophotometer. $\mathrm{K}$ was determined by Flame Photometer [13], while $\mathrm{Fe}, \mathrm{Zn}$ and $\mathrm{Mn}$ were determined using atomic absorption spectrophotometer using the method of A.O.A.C. [14]

\section{4) Statistical Analysis:}

All data were subjected to statistical analysis using Mstatc software. The comparison among means of the different treatments was determined, as illustrated by [15]. The Least Significant Differences Test compared means of the procedures at (0.05) level of significance.

\section{RESULTS AND DISCUSSION}

The results in Table (4) showed that a clear superiority of vermicompost compared to compost if $100 \%$ of the two are added. This shows the role of vermicompost more effectively than compost because vermicompost contains many growth regulators, vitamins and various nutrients and essential for plant growth. However, it is evident that the addition of vermicompost to organic compost given higher results than adding them individually. The highest values of branches number per plant, plant length $(\mathrm{cm})$, fresh and dry weight of shoot and bulb (g) and total green yield (ton fed ${ }^{-1}$ ) were obtained when using $50 \%$ vermicompost and $50 \%$ compost. Moradi et al., [16] indicated that mixing $50 \%$ compost with $50 \%$ vermicompost had positive effects on sweet fennel yield, as well as the combination of vermicompost and compost, has a higher effect on qualitative characteristics so that organic fertilizers can be considered as a suitable in improvement medicinal plant production systems. Vermicompost nitrates, phosphates and exchangeable calcium and soluble potassium [17]. Vermicompost is enriched with several advantageous microbes and also contains many essential nutrients like N, P and K [18]. Some studies have reported that adding vermicompost to soils lead to rising yield parameters of sweet fennel plants such as $[\mathbf{1 9 , 1 6}$.

Table 4: Effect of vermicompost and compost on growth and yield parameters of sweet fennel plants (Average of two seasons)

\begin{tabular}{|c|c|c|c|c|c|c|c|}
\hline \multirow{2}{*}{ Treatments } & \multirow{2}{*}{ Branches No/ plant } & \multirow{2}{*}{ Plant length $(\mathbf{c m})$} & \multicolumn{2}{|c|}{ Fresh weight (g) } & \multicolumn{2}{|c|}{ Dry weight (g) } & \multirow{2}{*}{$\begin{array}{l}\text { Total Green Yield } \\
\quad\left(\text { ton }_{\text {fed }}{ }^{-1}\right)\end{array}$} \\
\hline & & & Shoot & Bulb & Shoot & Bulb & \\
\hline T1 & 7.667 & 62.00 & 305.2 & 244.9 & 14.07 & 3.987 & 9.300 \\
\hline $\mathbf{T 2}$ & 6.667 & 59.33 & 338.3 & 247.8 & 14.40 & 3.660 & 9.667 \\
\hline T3 & 7.667 & 66.67 & 371.0 & 240.7 & 17.27 & 3.440 & 10.40 \\
\hline $\mathbf{T 4}$ & 7.667 & 61.00 & 360.5 & 294.2 & 17.23 & 4.733 & 10.50 \\
\hline T5 & 7.667 & 67.33 & 381.9 & 296.3 & 18.27 & 5.243 & 10.80 \\
\hline T6 & 8.333 & 70.00 & 398.3 & 309.0 & 19.33 & 5.280 & 11.03 \\
\hline $\mathrm{LSD}_{0.05}$ & 1.135 & 4.402 & 8.896 & 10.59 & 3.286 & 1.659 & 1.333 \\
\hline
\end{tabular}


As shown in (Table, 5), the addition of vermicompost improved the bulb dimensions (Length, width and thickness) of sweet fennel, especially when adding vermicompost at $100 \%$. However, there were no significant differences in improving the physical bulb quality of fennel bulb when adding vermicompost and compost.

Using mineral fertilizer for the crops is not so good for human health because of residual effect but organic fertilizer such as vermicompost or compost were increased the productivity of soil as well as yield quality without healthy harmful [20]. Chanda et al., [21] showed that vermicompost and compost can subtend the nutrient demand of field crops and significantly decrease the use of fertilizers and for vermicompost, in particular, it enhances soil fertility without contaminating the soil, as well as the quantity and quality of crops.

Table 5: Effect of vermicompost and compost on bulb dimensions and physical bulb quality of sweet fennel plants (Average of two seasons)

\begin{tabular}{|c|c|c|c|c|c|c|}
\hline \multirow{2}{*}{ Treatments } & \multicolumn{3}{|c|}{ Bulb dimensions $(\mathbf{c m})$} & \multicolumn{3}{c|}{ Physical bulb quality } \\
\cline { 2 - 7 } & Width & Length & Thickness & Flatten shape ratio & Elongated shape ratio & Cylinder shape ratio \\
\hline $\mathbf{T}_{\mathbf{1}}$ & 7.833 & 8.467 & 6.600 & 1.187 & 1.077 & 3.276 \\
\hline $\mathbf{T}_{\mathbf{2}}$ & 8.033 & 8.535 & 6.733 & 1.190 & 1.063 & 3.156 \\
\hline $\mathbf{T}_{\mathbf{3}}$ & 7.267 & 8.433 & 5.667 & 1.280 & 1.167 & 4.095 \\
\hline $\mathbf{T}_{\mathbf{4}}$ & 9.100 & 10.17 & 7.167 & 1.267 & 1.137 & 3.119 \\
\hline $\mathbf{T}_{\mathbf{5}}$ & 8.367 & 9.433 & 6.267 & 1.337 & 1.133 & 3.598 \\
\hline $\mathbf{T}_{\mathbf{6}}$ & 8.867 & 9.567 & 7.000 & 1.263 & 1.093 & 3.083 \\
\hline $\mathrm{LSD}_{0.05}$ & 1.133 & 1.053 & 0.716 & 0.115 & 0.081 & 0.540 \\
\hline
\end{tabular}

Data presented in Table (6) demonstrated that the N, P, K, Fe, Zn and Mn content in shoot and bulb of sweet fennel plants were significantly increased by the application of vermicompost. Also, the presence of vermicompost improved the nutrients content compared to the compost, even if the vermicompost was added to the compost in different proportions.

Vermicompost has higher nutritional value than traditional composts. This is due to the increased rate of mineralization and degree of humification by the action of earthworms [22]. Vermicompost contains essential nutrients, such as N, P, K, Ca, and Mg, which are facilely accessible to plants $[\mathbf{2 3 , 2 4}$. Vermicompost provide extra microsites for microbes to rise nutrients retention [25]. Nitrogen, $\mathrm{P}$, and $\mathrm{K}$ uptake were increased in rice plants when the addition of mineral fertilizer to vermicompost [26]. Vermicompost is a natural organic fertilizer produced by the earthworm. It releases the nutrients gradually into the soil [27]. Jat and Ahlawat [28] reported that vermicompost application enhanced soil nitrogen and phosphorus status in subsequent crops compared to no vermicompost application.

Table 6: Effect of vermicompost and compost on nutrients content in shoot and bulb of sweet fennel plants (Average of two seasons)

\begin{tabular}{|c|c|c|c|c|c|c|c|c|c|c|c|c|}
\hline \multirow[b]{2}{*}{ Treatments } & \multicolumn{6}{|c|}{ Shoot } & \multicolumn{6}{|c|}{ Bulb } \\
\hline & $\mathbf{N}$ & $\mathbf{P}$ & $\mathbf{K}$ & $\mathbf{F e}$ & $\mathbf{Z n}$ & Mn & $\mathbf{N}$ & $\mathbf{P}$ & $\mathbf{K}$ & $\mathrm{Fe}$ & $\mathbf{Z n}$ & Mn \\
\hline & \multicolumn{3}{|c|}{$\%$} & \multicolumn{3}{|c|}{ ppm } & \multicolumn{3}{|c|}{$\%$} & \multicolumn{3}{|c|}{ ppm } \\
\hline $\mathrm{T}_{1}$ & 1.203 & 0.280 & 2.443 & 152.5 & 11.87 & 22.60 & 0.697 & 0.537 & 3.083 & 249.9 & 14.93 & 19.33 \\
\hline $\mathrm{T}_{2}$ & 1.447 & 0.463 & 3.190 & 170.2 & 17.17 & 22.20 & 0.537 & 0.557 & 3.380 & 300.1 & 17.97 & 29.40 \\
\hline $\mathrm{T}_{3}$ & 1.503 & 0.597 & 2.530 & 176.1 & 16.23 & 22.20 & 0.590 & 0.827 & 3.847 & 292.8 & 24.37 & 29.10 \\
\hline $\mathrm{T}_{4}$ & 1.387 & 0.327 & 2.740 & 268.8 & 16.80 & 26.47 & 0.730 & 0.513 & 3.393 & 253.3 & 14.67 & 21.27 \\
\hline $\mathrm{T}_{5}$ & 1.407 & 0.313 & 3.007 & 214.1 & 16.20 & 22.80 & 0.740 & 0.637 & 3.827 & 256.3 & 15.17 & 20.23 \\
\hline $\mathrm{T}_{6}$ & 1.327 & 0.387 & 3.700 & 173.6 & 20.37 & 23.13 & 0.793 & 0.770 & 3.960 & 257.3 & 17.37 & 22.07 \\
\hline $\mathrm{LSD}_{0.05}$ & 0.115 & 0.141 & 0.215 & 1.113 & 0.237 & 0.257 & 0.057 & 0.163 & 0.501 & 3.933 & 1.289 & 1.621 \\
\hline
\end{tabular}

\section{CONCLUSION}

The superiority of vermicompost compared to compost if the two are added to sweet fennel grown in sandy soil. Vermicompost is an exemplary organic fertilizer for bestead growth and high yielding of crops. Vermicompost has higher nutritional value than traditional composts. The role of vermicompost more effectively than compost due to the fact that vermicompost contains many growth regulators, vitamins and various nutrients and essential for plant growth.

\section{REFERENCES}

[1] Telci I, Demirtas I. and Sahin A., (2009). Variation in plant properties and essential oil composition of sweet fennel (Foeniculum vulgare Mill.) fruits during stages of maturity. Ind. Crop Prod. 30, 126-130.

[2] Marino S.D., Gala F., Borbone N., Zollo F., Vitalini S., Visioli F. and Iorizzi M. (2007). Phenolic glycosides from Foeniculum vulgare fruit and evaluation of antioxidative activity. Phytochem 68, 1805-1812. 
[3] Abou El-Magd M.M. and M.S. El-Basiony (2013). Foliar nutrition of two sweet fennel cultivars affect their vegetative growth, green yield and bulb quality. Journal of Applied Sciences Research, 9: 2788-2796.

[4] Atiyeh R. M., S. Subler1, C.A. Edwards, G. Bachman, J. D. Metzger and W. Shuster (2000). Effects of vermicomposts and composts on plant growth in horticultural container media and soil. Pedo biologia, 44, 579-590.

[5] Saad Abou-El-Hassan, Hassan G. Elmehrat, Wael M. Ibrahim and Atef A. Ragab (2019). Applying biofertilizer and different rates of compost for the production of squash. Middle East Journal of Applied Sciences 9: 319-325.

[6] Cardoso, L., and E. Ramírez (2002). Vermicomposting of sewage sludge: A new technology for Mexico. Water Science Technology 46: 153-158.

[7] Suthar, S. (2007). Vermicomposting potential of Perionyx sansibaricus (Perrier) in different waste materials. Bioresource Technology 98: 1231-1237.

[8] Yadav, S., and V.K. Singh (2014). Vermitechnology: Rebuilding Sustainable Rural Livelihoods. New York: Nova Science Publishers.

[9] Sabrina, D. T., M. M. Hanafi, A. W. Gandahi, M. T. Muda Mohamed and Abdul Aziz, N. A. (2013). Effect of mixed organicinorganic fertilizer on growth and phosphorus uptake of setaria grass (Setaria splendida). Australian Journal of Crop Science, 7, 75-83.

[10] Chavda, V. N. and B. S. Rajawat (2015).Performance evaluation of vermicompost on yield of Kharif groundnut and cotton crops. International Journal of Forestry and Crop Improvement. 6(2), 127-131.

[11] Cottenie, A. (1980). Soil and plant testing as a basis of fertilizer recommendation. F.A.O. Soil Bull.

[12] Pascale, S. D. and G. Barbieri (1995). Effect of soil salinity from long term irrigation with saline sodic water on yield and quality of winter vegetable crops. Sci. Hort., 64: 145-157.

[13] Champman H. D and P. E. Pratt (1961). Methods of Analysis for soils, plants and water, Davis Agric. Sci. Pull of Fice Calif. Univ. pp. 220-308

[14] A.O.A.C. (1990). Official Methods of Analysis, Association of Officinal Analytical.

[15] Snedecor, G. W. and W. G. Cochran (1982). Statistical Methods. $7^{\text {th }}$ ed. Iowa State Univ. Press, Iowa, U.S.A.

[16] Moradi R. , P. Rezvani Moghaddam , M. Nasiri Mahallati and A. Nezhadali (2011). Effects of organic and biological fertilizers on fruit yield and essential oil of sweet fennel (Foeniculum vulgare var. dulce). Spanish Journal of Agricultural Research , 9: 546-553.

[17] Atiyeh, R.M., S.S. Lee, C.A. Edwards, N.Q. Arancon and J. Metzger (2002). The influence of humic acid derived from earthworm-processed organic waste on plant growth. Bioresource Technology 84, 7-14.

[18] Sinha .J, Biswas C.K., Ghosh A. and Saha A. (2010). Efficacy of vermicompost against fertilizers on Cicer and Pisum and on population diversity of N2 fixing bacteria. J. Environ. Biol. 31: 287-292.

[19] Darzi M.T., Ghalvand A., Sefidkon F. and Rejali F. (2009). The effects of mycorrhiza, vermicompost and phosphatic biofertilizer application on quantity and quality of essential oil in fennel (Foeniculum vulgare Mill.). Iran J Med Aroma Plants 24: 396-413.

[20] Tindall, M., (2000). Mineral and organic fertilizing in cabbage. Residual effect for commercial cultivation on yield and quality performance with organic farming. Hort. Bras., 6:15-20.

[21] Chanda, G. K., Bhunia, G. and Chakraborty, S. K. (2011). The effect of vermicompost and other fertilizers on cultivation of tomato plants. Journal of Horticulture and Forestry, 3 (2), 42-45.

[22] Albanell E.,J. Plaixats and T. Cabrero (1988). Chemical changes during `vermicomposting (Eisenia fetida) of sheep manure mixed with cotton industrial wastes. Biol Fertil Soils 6:266-269.

[23] Pathma, J. and N. Sakthivel (2012). Microbial diversity of vermicompost bacteria that exhibit useful agricultural traits and waste management potential. Springer Plus, 1:(1), 26.

[24] Lim, S. L., T. Y. Wu, P. N. Lim and K. P. Y. Shak (2015). The use of vermicompost in organic farming:Overview, effects on soil and economics. Journalof the Science of Food and Agriculture, 95(6):1143-1156.

[25] Ali, U., Sajid, N., Khalid, A., L. Riaz, M. M. Rabbani, J. H. Syed and R. N.Malik (2015).A review on vermicomposting of organic wastes.Environmental Progress \& Sustainable Energy, 34(4), 1050-1062.

[26] Thirunavukkarasu, M. and R. Vinoth (2013). Influence of vermicompost application along with nitrogen on growth, nutrients uptake, yield attributes and economics of rice (Oryza sativa L.). International Journal of Agricultural, Environment and Biotechnology, 6(4), 599-604.

[27] Chaoui, H. I., L. M. Zibilske and T. Ohno (2003). Effects of earthworms casts and compost on soil microbial activity and plant nutrient availability. Soil Biology and Biochemistry, 35 : 295-302.

[28] Jat R. S. and I. P. S. Ahlawat (2006). Direct and residual effect of vermicompost, biofertilizers and phosphorus on soil nutrient dynamics and productivity of chickpea-fodder maize sequence. J Sustain Agric, 28(1):41-54. 